\title{
Durkheim's totemic principle, shamanism and Southern African San religions
}

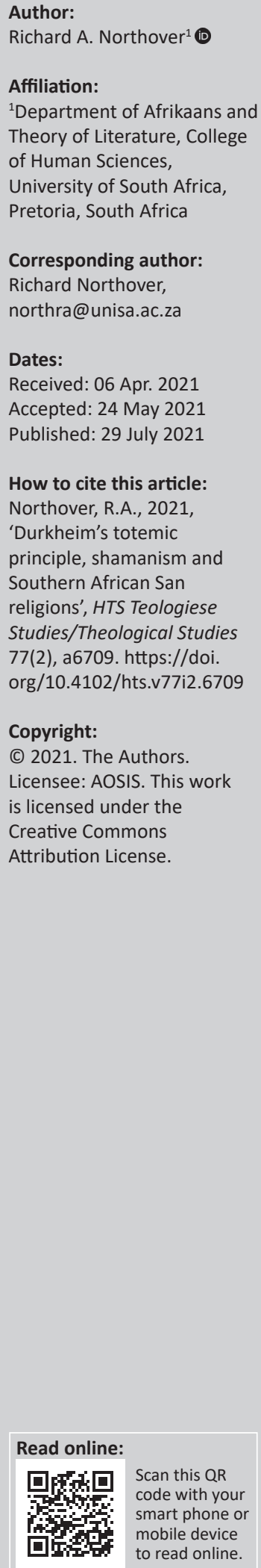

The study reappraised Emile Durkheim's totemic principle in relation to the origins of religion and culture, using, amongst others, speech act theory and recent southern African epistemologies, especially David Lewis-Williams' theory of shamanism, potency and altered states of consciousness. The study was text-based, qualitative and interpretive, and used key texts from anthropology, archaeology, history of religion, sociology and philosophy. It outlined Durkheim's theory of the totemic principle and critiqued it, using performativity, cognitive neuroscience and southern African ethnography. Durkheim's sociological reduction of God and religion to society and his dismissal of individual psychological experience were criticised. Lewis-Williams' shamanism, both as a general theory and with particular reference to the San, was explored as an alternative to Durkheim's totemism, animals playing a central but different function in each system. Although his understanding of performativity and sociopolitical relations in religion was inchoate, Durkheim helped demystify religion and establish social constructionism. He overestimated collective affect and sentiments and underestimated the role played by individual altered states of consciousness in the origin of religion.

Contribution: The study critically evaluates Durkheim's reduction of religion to society using current concepts of performativity, Matthias Guenther's New Animism and David Lewis-Williams' revised shamanism, particularly its ideas of trance dance, potency and altered states of consciousness, and posits shamanism rather than totemism as the probable origin of religion.

Keywords: Emile Durkheim; totemism; mana; David Lewis-Williams; San; shamanism; potency; animism; altered states of consciousness.

\section{Introduction}

This study critiques Durkheim's concept of the totemic principle elaborated in The elementary forms of the religious life ([1915] 2013). Effectively, Durkheim argued that totemism is the most basic religion, that the totemic principle represents in the minds of its adherents a universal, impersonal supernatural power (or life force), but that this force really represents the moral and epistemological power of society. The study argues that David Lewis-Williams' shamanistic theory critically illuminates aspects of Durkheim's theory of totemism and acts as a corrective to Durkheim's exclusion of the religious experiences of southern African San hunter-gatherer peoples, whose traditions are very ancient, evident in the facts that the San did not cultivate, venerate ancestors or practise blood sacrifice and arguably share shamanistic features with the hunter-gatherer cultures of the Ice Age. The birdman of Lascaux (c. 25000 BCE) is arguably the earliest depiction of a shaman or ur-shaman (ritual specialist). The ochre stick inscribed with geometric patterns found in Blombos Cave (c. 75000 BCE) may be the earliest evidence of symbolic thought (Lewis-Williams 2004:22-25) and may depict certain patterns experienced in altered states of consciousness. Contra Durkheim, this article argues that shamanism rather than totemism represents the earliest form of religion, that shamanism presupposes animism and that religious sentiment originates primarily in individual psychological experience rather than collective sentiment.

\section{Methodology and critical caveats}

The study is interdisciplinary, interpretive and qualitative, and makes use of key texts in totemism and shamanism. As the study is purely text-based, its ethical risk level is negligible. Besides the archaeological, ethnographical and cognitive neuroscientific approaches used by Lewis-Williams,

Note: Special Collection: Re-readings of Major Theorists of Religion: Continuities and Discontinuities, sub-edited by Mohammed (Auwais) Rafudeen (University of South Africa). 
the study makes use of structural anthropologist Claude Lévi-Strauss' Totemism ([1961] 1964) and the historians of religion Mircea Eliade's Shamanism: Archaic Techniques of Ecstasy ([1964] 2004) and Nicolas Meylan's (2017) Mana: A History of a Western Category to critique Durkheim's functionalist sociological approach and theory. It also considers speech act theory's concept of performativity to illuminate aspects of Durkheim's argument. Finally, it notes the recent work of the anthropologist Guenther $(2017,2020 a$, $2020 \mathrm{~b}$ ) on the New Animist paradigm in opposition to Durkheim's rejection of animism as a possible origin of religion.

Before proceeding, some cautionary remarks are required about the use of some key terms used in the scientific study of religions by Westerners, specifically 'totem', 'mana' and 'shaman'. Each term originates in an indigenous language of a so-called primitive society but has subsequently been applied more broadly by scholars to cover similar phenomena in different societies. This article, following Meylan, uses italics to indicate the indigenous use of these terms, no italics (roman) to indicate their use in Western scholarly contexts and inverted commas when discussing the term as a word. The term 'totem' comes from Ojibwa, an Algonquian language spoken by a Native American tribe (Lévi-Strauss [1961] 1964:18). Concerning totemism, LéviStrauss ([1961] 1964) pointed out that:

This collective naming system is not to be confused with the belief, held by the same Ojibwa, that an individual may enter into a relationship with an animal which will be his guardian spirit. (p. 18)

David Whitley (2009:149) noted that "The term "shaman," which entered the ethnographic literature from studies of the Tungus peoples in Siberia, is a loan word from another language, perhaps Sanskrit'. Even though this suggests that the word itself is a relatively recent development, the term may have wide applicability to hunter-gather peoples across the planet and deep into the past. Meylan (2017) traced the origin of the term 'mana' in Melanesia and showed how it was appropriated by Western scholars and applied to contexts often quite differently from the one it originated in.

In addition to this, Lewis-Williams is highly critical of terms and distinctions like 'religion', 'art', 'sacred/profane' and 'supernature/nature', which he believes are heavily laden Western terms that may obscure the understanding of the cultures to which they are often applied. His theory, like Durkheim's, has sometimes been criticised as a reductive and totalising system, as it is based on the neurological structure common to all human beings, a criticism this study rejects. The title of Lewis-Williams and Thomas Dowson's ground-breaking paper, 'The signs of all times: Entoptic phenomena in Upper Palaeolithic art' (1988), was bound to meet resistance from scholars who shied away from universals and theories and who insisted only on differences and empirical particularities. Another key term is 'animism', which, although one that Lewis-Williams tends to avoid, does seem implicit in shamanism. This is clear in the work of Guenther (2017, 2020a, 2020b), who has recently argued for the introduction of the New Animist paradigm, originating in South America, into southern African anthropology and archaeology, as it suits the relational ontology and the ontological flux found in San religion (and hunter-gatherer societies generally), both in their myths and rock art and in the transformation of shamans in trance, usually into the form of spirit animals in trans-cosmological journeys. In two recent essays $(2015,2017)$ and his two-volume publication (Guenther 2020a, 2020b), he introduces New Animism to South African anthropology and archaeology, describing it as an 'ontological turn' and defining it as a 'relational ontology' characterised by 'ontological flux and ambiguity', departing from Tylor's evolutionary approach. He wrote that:

This study, of 'San-animism', also underscores the important insight that animism is not some monolithic schema or cosmologico-religious complex but something diverse and multiplex, structurally varied, ecologically and historically contingent. (Guenther 2020a, 2020b:ix)

A final cautionary note concerns the fact that the term 'totemism' has fallen out of use, as Lewis-Williams (2002:46-47) pointed out, citing Claude Lévi-Strauss' Totemism ([1961] 1964) in an end note. In fact, Lévi-Strauss observed that the concept or theory of totemism had already been thoroughly debunked by the time he was writing his book in the late 1950s and he ([1961] 1964) expressed concern that:

To accept as a theme for discussion a category that one believes to be false always entails the risk, simply by the attention that is paid to it, of entertaining some illusion about its reality. (p. 15)

\section{Durkheim's totemic principle}

Central to Durkheim's investigation of totemism, in opposition to naturism and animism, as the origin of religion in The Elementary Forms of the Religious Life ([1915] 2013) is his distinction between the sacred and the profane expressed in his definition of religion:

A religion is a unified system of beliefs and practices relative to sacred things, that is to say, things set apart and forbidden beliefs and practices which unite into one single community called a Church, all those who adhere to them. The second element which thus finds a place in our definition is no less essential than the first; for by showing that the idea of religion is inseparable from that of the Church, it makes it clear that religion should be an eminently collective thing. (p. 53)

Indeed, he stated as the central thesis of his book:

The general conclusion of the book which the reader has before him is that religion is something eminently social. Religious representations are collective representations which express collective realities; the rites are a manner of acting which take rise in the midst of the assembled groups and which are destined to excite, maintain or recreate certain mental states in these groups. So if the categories are of religious origin, they ought to participate 
in this nature common to all religious facts; they too should be social affairs and the product of collective thought. (p. 17)

Durkheim criticised both Tylor's animist and Max Müller's naturist theories for trying to create religion, essentially the sense of the sacred, from nothing, that is, creating a supernatural realm from the experience of natural phenomena or from linguistic errors (specifically metaphor) ([1915] 2013:94).

Much later, Durkheim ([1915] 2013:432) wrote, 'Our entire study rests upon this postulate that the unanimous sentiment of the believers of all times cannot be purely illusory'. Durkheim ([1915] 2013:48) noted that even though the sacred or profane distinction assumes things radically different in kind, there is 'nothing sensible experience seems able to suggest the idea of so radical a duality to them'. Durkheim's answer is that all religious rites and rituals are expressions of society (rather than a spirit realm), that is, our moral order or our collective life. However, he was unaware of a third sphere of experience that of altered states of consciousness, a central aspect of shamanism explored later in this article.

After criticising animism and naturism, Durkheim proceeded to investigate totemism as the possibly earliest form of religion, applying a term originating in North America to Australian aboriginal societies. He pointed out (Durkheim [1915] 2013:108-109) how Australian tribes, phratries and clans are represented by (emblems of) animal species (or part of an animal) and less usually a plant or natural phenomenon (sun, moon, stars, water). He shows how the totems within a tribe, and between the phratries, clans and matrilineal groups, work together to categorise all things in the cosmos (Durkheim [1915] 2013:152).

Durkheim, therefore, saw no discontinuity between religious thinking and scientific thinking and argued that totemism was one of the earliest attempts to categorise the universe systematically, besides uniting a group of people in a moral community. Concluding his analysis of totemism, Durkheim ([1915] 2013) argued that:

In other words, totemism is the religion, not of such animals or men or images, but of an anonymous and impersonal force, found in each of these beings but not to be confounded with any of them. No one possesses it entirely and all participate in it. It is so completely independent of the particular subjects in whom it incarnates itself, that it precedes them and survives them... Taking the words in a large sense, we may say that it is the god adored by each totemic cult. Yet, it is an impersonal god, without name or history, immanent in the worlds and diffused in an innumerable multitude of things. (pp. 188-189)

Central to Durkheim's ([1915] 2013) argument is his assertion that:

The god of the clan, the totemic principle, can therefore be nothing else that the clan itself, personified and represented to the imagination under the visible form of the animal or vegetable which serves as totem. (p. 211)
In the next section, he reduces 'god' to 'society':

In a general way, it is unquestionable that a society has all that is necessary to arouse the sensation of the divine in minds, merely by the power that it has over them; for to its members it is what a god is to his worshippers. (p. 212)

Durkheim does the same with the sacred as he does with totemism, that is, he reduces it to the notion of religious forces (or a religious force), which also explains the mobility and contagiousness of the sacred ([1915] 2013:333).

In seeking confirmation for his analysis, Durkheim elaborated on the various Native American tribes' names for the universal life force, variously named wakan, orenda, pokunt, manitou and so on. He quoted Hewitt:

'The savage man ... conceived the diverse bodies collectively constituting his environment to possess inherently mystic potence ... This potence is held to be the property of all things ...'. A sorcerer or shaman has orenda, but as much would be said of a man succeeding in his enterprises. At bottom, there is nothing in the world that does not have its quota of orenda; but the quantities vary. (p. 197)

Durkheim noted that, even though they have advanced beyond totemism, the Melanesians call this power mana ([1915] 2013:194). Both Smith (2004) and Meylan (2017) have criticised this move in Durkheim's argument. Smith (2004:203-207) pointed out how Durkheim departed from his strict methodology of adhering to the empirical facts, as recorded by ethnographers, by borrowing the term 'totem' from Native American studies to apply to Australian society for which no evidence of 'an impersonal force' is available. He did so by equating the totemic principle with the term 'mana', borrowed from Melanesia, although filtered through Western scholarship. Meylan (2017) criticised the scholars who, since Codrington introduced the term 'mana' in the late 19th century, applied it widely outside of its original context. According to Meylan (2017:43-44), Codrington defined 'mana' as a universal, impersonal force, in opposition to Tylor's animism, which posited individual, personal spirits. He pointed out how Durkheim needed this abstract notion of mana, which he equated with the totemic principle, to advance his sociological argument that mana ultimately represents social forces and collective human agency. Further criticisms of Smith and Meylan are addressed later, as is Lewis-Williams' use of the term 'potency', in critical comparison with Hewitt's 'mystic potence'.

Durkheim ([1915] 2013) argued that this idea of a universal, impersonal spiritual force is equally applicable to the simple religions:

But since it is impossible to go lower than totemism, we are not exposed to this risk of error, and at the same time, we have an opportunity of finding the initial notion from which the ideas of wakan and mana are derived: this is the notion of the totemic principle. (p. 203)

Durkheim noted that this notion is of interest not just to religious but also to scientific thought: 'It is the first form of 
the idea of force' ([1915] 2013:207) and sees totemism also as the forerunner of the modern scientific notion of causality. He discussed the primitive notion of causality that 'like produces like' ([1915] 2013:376) and, once again, reduces it to collective social action ([1915] 2013:376-377) and ultimately to political power relations ([1915] 2013:379), those of hierarchy, domination and subordination. However, it is not a purely physical force: 'It is from it that all life comes; "all life is wakan"; and by this word life we must understand everything that acts and reacts, that moves and is moved, in both the mineral and biological kingdoms' (Durkheim [1915] 2013:207).

Durkheim goes on to suggest that the origin of the belief in both god and society is the same. In fact, god is society ([1915] 2013:212, 214). In particular, the sacred is the moral power that society imposes on us in order to make social life possible (Durkheim [1915] 2013:214).

Smith (2004) discussed a further questionable stratagem in Durkheim's argument concerning the tjurunga, an object of wood or stone considered sacred to Aboriginal people from Central Australia:

As I have argued elsewhere, the linchpin of Durkheim's argument is the observation that 'in themselves, the tjurunga are merely objects of wood and stone like so many others; they are distinguished from profane things of the same kind by only one particularity: the totemic mark is drawn or engraved upon them. That mark, and only that mark confers sacredness upon them' $(172 / 121)$. It is the nature of these 'marks' that interests Durkheim and provides him with his key argument. The marks are nonrepresentational, they do not represent natural 'things'. Hence, they are to be derived from social rather than from sensory experience. While the argumentative move, not natural and therefore social, is a hallmark throughout Durkheim's work, here he develops a linguistic analogy. (pp. 208-209)

This article is less concerned about the linguistic analogy than it is about the logic: non-representational, therefore social, and therefore the 'geometric designs' must have a conventional meaning. For there is a third possibility of which Durkheim seemed unaware, the possibility that the geometric designs could represent the geometric images, or what Lewis-Williams calls 'entoptics', that trancers experience in the first stage of altered states of consciousness. This is explored later in the article. It suffices for now to point out that this key piece of evidence, rather than corroborating totemism, may actually corroborate shamanism.

\section{Performativity and social power}

On the other hand, Durkheim's ideas do gain some support from a branch of philosophy called as speech act theory, which aligns with his nascent social constructionism. In The Construction of Social Reality (1995), the philosopher Searle (1995) acknowledged his indebtedness to the founders of the social sciences - Weber, Simmel and Durkheim - but noted that:
They were not in a position to answer the questions that puzzle me, because they did not have the necessary tools. That is, through no fault of their own, they lacked an adequate theory of speech acts, of performatives, of intentionality, of collective intentionality, of rule-governed behaviour, etc. (p. 8)

Austin was the founder of speech act theory and performatives, and Searle developed it further. However, both considered speech acts as rule-governed forms of behaviour in relatively depoliticised forms of the theory, although they recognised that for certain speech acts to be felicitous, an authority figure had to pronounce the words and or produce the gestures. It took Jacques Derrida (1986, 1988) and Judith Butler (2015) to politicise speech act theory. As a matter of fact, Durkheim wrote, when distinguishing between beliefs and rites and between the sacred and the profane, that "There are words, expressions and formulae which can be pronounced only by the mouths of consecrated persons; there are gestures and movements which everybody cannot perform' ([1915] 2013:43). This comes quite close to an understanding of performativity and suggests a link between the sacred, authority, performativity and power, as it presupposes social stratification and unequal power relations.

Indeed, performativity is implicit in Durkheim's ([1915] 2013) discussion of the collective social force that God represents, and the way a collective assembly raises the feelings and capacities of the people who participate in them, enabling them to transcend themselves, when, in the context of the French revolution, he cited:

The night of the Fourth of August, 1789, when an assembly was suddenly led to an act of sacrifice and abnegation which each of its members had refused the day before, and at which they were all surprised the day after. (p. 215)

As Petrey (1988) shows, central to the French Revolution was of a series of speech acts called performatives, or declaratives, in which merely by declaring something to exist, the declaration brings about the very fact into existence, or, as Austin (1976:12) puts it, 'to say something is to do something'. This applies not just to the abolition of feudalism by the National Assembly (which had declared itself into existence) but also to the Declaration of the Rights of Man, the declaration of war against neighbouring countries and so on. However, Durkheim was writing more about collective affects and sentiments, which Lévi-Strauss criticises ([1961] 1964:97), than the efficacy of the performative speech acts, which is a form of social power, even though performativity was implicit in what he wrote. Durkheim may have intuited the power of performativity in the totemic principle (mana, orenda, wakan, manitou and so on), although he failed to link it to the power of influential figures in 'primitive' societies.

\section{Meylan's political critique of 'mana'}

Meylan (2017:9), in his critique of the Western appropriation of the Melanesian notion of mana, cited Austin and Searle when noting how the term mana was used as a performative 
in a Melanesian ceremony. Meylan (2017:82) discussed Durkheim's sociological and positivist theory of religion as collective belief and action but pointed out, when criticising scholars for depoliticising mana, in a footnote, that 'Durkheim, who mentions the correlation of mana and power, represents an exception, but this does not lead him to a discussion of political power'. However, Meylan omitted to mention that Durkheim used the example of the National Assembly's abolition of feudalism in 1789 as an example of collective action, which can, in fact, be identified as an example of a performative - a declarative speech act. Nonetheless, Meylan's (2017) basic criticism remained pertinent that all the scholars, including Durkheim, who used the concept of mana outside of its original context were guilty of occultising, mystifying and naturalising a concept that was, even in its original context, inescapably political:

I have shown above that Codrington's mana represents, to borrow Lincoln's happy expression, a mystification of success ... In the Melanesians (Codrington 1891), mana can indeed be analysed as a discourse that effects the cloaking of the social and economic bases of power. (p. 169)

Contrasting ethnography and anthropology (and slightly favouring the former's particularism), Meylan (2017) argued:

The failure of mana as a theoretical category lay not so much in issues of semantics as in the occultation of its pragmatics. Theorists of mana forgot, or perhaps could not see, that in Oceana mana was tightly linked with precise individuals [and therefore with sociopolitical relations] ... It would appear then that the problem is less that of the impossibility of generalizing mana than the failure of taking into account a central element of the term - its pragmatics. Rather than treat mana as a word, concept and/or category, it should be dealt with as a discourse, as 'language in use'. (p. 175)

\section{Shamanism, animism and Southern African San religions}

This political criticism cannot be levelled at the shamanistic theory of Lewis-Williams, as his Marxism predisposes him to find social differentiation and conflict in social structure, whereas Durkheim's functionalism sees religion as functioning to achieve social unity. Lewis-Williams argued in Chapter 3 of The Mind in the Cave (2002) that art (imagemaking) arose out of social conflict and social differences, not only within and between human communities but also between humans and Neanderthals, as the latter could not understand symbols. Art divided as much as it unified human communities and involved relations of power and, even, domination. He (Lewis-Williams 2002) argued that:

Mystics are people who exploit the autistic end of the spectrum of consciousness [that is, dreams, trance states and visions] not only for their personal gratification but also to set themselves apart from others. (p. 190)

Something similar occurred during the Upper Palaeolithic Transition (45 000-35000 BCE), when humans who could exploit altered states of consciousness and dreams, felt the need to distinguish themselves from Neanderthals, and could not exploit the autistic end of the spectrum of consciousness (Lewis-Williams 2002):

Neanderthals were congenital atheists, Homo sapiens' more advanced ability in this mental arena may have made it important for them to cultivate the distinction by (in part) manifesting their visions as two- and three-dimensional images. (p. 192)

His Marxism, therefore, adds a politically critical dimension to his indebtedness to Eliade's somewhat ahistorical and essentialist Shamanism: Archaic Techniques of Ecstasy ([1964] 2004). Although he rarely explicitly mentions Eliade, he shared with him the ideas of the shaman as ritual expert of trance, cosmological travel, a three-tiered cosmos and the axis mundi as a portal to the upper and lower spirit realms. Eliade ([1964] 2004:503-504) discussed the birdman of Lascaux as a depiction of ecstatic flight and, therefore, of shamanism, if in a nascent form, and Whitely (2009) argued for the shamanic status of the bison-men of Chauvet Cave and Le Trois Freres. Departing slightly from Eliade, Whitley revived Raymond Firth's definition of 'the shaman not as an expert in ecstasy but as the master of the spirits' (Whitley 2009:206), which suggests a close link between animism and shamanism.

Lewis-Williams extended and grounded Eliade's approach, which was limited to ethnological records, by making use of the findings of cognitive neuroscience, specifically those concerning altered states of consciousness, which are hardwired into the human brain. Where Eliade wrote somewhat imprecisely about trance and ecstasy (Whitley 2009:193), Lewis-Williams (2004), and Lewis-Williams and Pearce (2005) described a spectrum of consciousness with alert, awake, aware states on the one end, moving through states like daydreaming before bifurcating at the 'autistic' end between a descending trajectory and an ascending trajectory. The descending trajectory moves through hypnogogic states to dreams and, ultimately, to unconscious states. The ascending, intensified trajectory moves into trance states, or altered states of consciousness, which involve three stages.

The first stage involves the perception of entoptic phenomena, geometrical images in constant flux that are internal to the eye, including zig-zags, waves, triangle, spirals, dots and nested images, amongst others. These geometrical images have been found in hunter-gatherer 'religious' art throughout history and pre-history and across the planet. The second stage involves construal of the entopic images into cultural and natural objects familiar to the person in trance. Then there is the vortex, a passage with light at its far end and often with objects embedded in its walls. Finally, stage three consists of full-blown visual, auditory and somatic hallucinations, sometimes the hallucination of becoming animal. These stages do not follow each other mechanically and sometimes stages are skipped or returned to.

Furthermore, these altered states were manipulated in different ways by different individuals in different cultures. Lewis-Williams argued that shamans, at least in southern 
Africa, were able to exploit their altered states of consciousness in rituals and image-making to obtain differential social treatment. They would claim that they accessed the spirit world in their trance state in trans-cosmological forays into the spirit world to obtain potency for the purposes of healing, rain-making, fending off sickness and enemies and assisting with the hunt. Eliade ([1964] 2004:92-95) noted that shamans transformed into spirit animals to access the spirit world, a belief also shared by the San. The portals used by southern African shamans differ somewhat from those described by Eliade, as they involve not just mountains and holes in the ground, and rarely trees, but, instead, water holes, threads of light, rock shelters and the rock surfaces upon which images were etched and painted. Although Lewis-Williams questioned the term, some would consider these to be 'sacred' spaces, what Eliade ([1964] 2004:260) called 'a Center, or site of possible break-through in plane'.

Lewis-Williams (2005) criticised Durkheim's sociological reduction of God and religion to society:

... Emile Durkheim famously denounced 'reducing' religion, which he saw as a social phenomenon, to a psychological one. Crudely put, the social explanation says that, in worshipping God, society is paying homage to a reified form of itself (an extraordinarily vague notion). No one would deny that religion plays a key role in many societies and that it is sometimes hard to distinguish between religion and politics, but it is its psychological and emotional components that trigger much of its appeal and that facilitate its potential reach to every member of society. (p. 24)

In fact, Durkheim ([1915] 2013) mentioned the affective forces, although socially mediated or collective ones, just before he discussed the Fourth of August 1789:

In the midst of an assembly animated by a common passion, we become susceptible of acts and sentiments of which we are incapable when reduced to our own forces; and when the assembly is dissolved and when, finding ourselves alone again, we fall back to our ordinary level, we are then able to measure the height to which we have been raised above ourselves. (p. 215)

\section{Somewhat later, Durkheim ([1915] 2013) wrote:}

In fact, we have seen that if collective life awakens religious thought on reaching a certain level of intensity, it is because it brings about a state of effervescence which changes the conditions of psychic activity. Vital energies are over-excited, passions more active, sensations stronger; there are even some which are produced only at this moment. (p. 437)

However, these are precisely the collective sentiments that Lévi-Strauss finds unconvincing ([1961] 1964:97). It also concerns the sentiments of the collective, or whole community, as opposed to the even more intense trance experiences of the ritual specialist, or shaman, which is the focus of Lewis-Williams' theory. Eliade ([1964] 2004:205), too, described the difference between the religion of the collective and the religion of the ritual specialists, which did not always coincide very closely.
Indeed, as Whitley (2009:224) pointed out, shamans in Native American societies, at least in northern California, tended to be solitary figures, even dangerous outsiders. Their vision quests were solitary in contrast to the communal trance dance of the southern African San. Shamans in various hunter-gatherer cultures induce trance states in ritual situations either using psychoactive plant substances or, in the case of the Southern African San, using the trance dance, which, according to Guenther (1999:181), 'is the central ritual of Bushman religion and its defining religious institution'. The shamans would later, when no longer in a trance state, record their visionary experiences in rock engravings and paintings, usually in 'sacred' places. Ultimately, it is difficult to conceive of shamanism without some form of animism, as animal spirits are central to hunter-gatherer myth and ritual.

Guenther (1999:6) argued that 'The Bushman religious figures of greatest interest to the student of comparative religion are the trance dancer and the trickster. According to him, San religion lacks a strong structure and hierarchy and is characterised instead by ambiguity and ontological flux. He emphasised transformation (into animal forms) and transcendence, noting that:

The trickster and the trance dancer are the two central, key figures of Bushman religion ... who dramatically bear out its basic (anti)structural constitution. We will see the trickster figure as the embodiment of the ambiguity that pervades Bushman mythology and cosmology, much the same as the trance dancer embodies this state with respect to ritual. (p. 4)

The trickster figure ambiguously combines both the revered Creator god and the mischievous trickster god, especially evident in his (mis)adventures in San myth. Furthermore (Guenther 1999):

The second major category, the trance dancer, whom I (following Lewis-Williams) refer to as a shaman, is a figure rarely encountered in African religious studies, wherein spirit possession, divination, witchcraft and sorcery constitute the predominant forms of preternatural operation and machination ... As the Bushman trickster forces definitional reconsiderations, so does the trance dancer-shaman, who does not fit into the classic Siberian-derived category of shaman (because he does not experience spirit possession). Yet, with altered states of consciousness, as well as outer-body travel as his principal modus operandi, and curing and hunting as his main spheres of ritual activity, the Bushman trance dancer falls in line, more or less, with shamanic figures in other parts of the world. (p. 7)

Guenther (2020b), however, allowed for cross-borrowings between San and Bantu cultures, especially following the foraging nature of San societies:

While integral to San cosmology and ontology, as part of their hunting lifeways and therianthrope- and transformationinformed mythology and ritual, animal mimesis and metamorphosis thus has to be considered also in the context of San people's contact with Bantu-speaking peoples. (p. 113)

Despite the centrality of animals in San cosmology, myth and ritual, totem animals are almost entirely absent from hunter- 
gatherer cultures, except in rare instances where such cultures co-existed alongside cultivator societies from which they borrowed this institution (Guenther 2020b:113).

In his attempt to refute Tylor's theory of animism, Durkheim argued that 'If it were true, it would be necessary to admit that religious beliefs are so many hallucinatory representations, without any objective foundation whatsoever' (p. 76). Such a belief would be unsustainable against the facts of reality, that is, dreams as the source of the belief in a double (i.e. the body and the soul, or awake versus sleeping states). However, the impersonal universal life force that he identifies at the heart of all religions is itself not perceivable, which is why he locates it in society, whose rituals and activities are perceivable. A further criticism of Durkheim, as argued below, is that the basis of religion may very well be in subjective altered states of consciousness embodied in the performances and imageproduction of the shaman ritual specialist.

This is precisely the value of Lewis-Williams' theory of shamanism and altered states of consciousness, because the accelerated branch of altered states provides 'out of this world' experiences. This is the reason, too, that Froese (2011) and Froese et al. (2016) considered Lewis-Williams' theory of altered states of consciousness as a possible answer precisely to the question that Durkheim poses, in Froese's terms the origin of culture rather than specifically religion, concerning something that transcends merely immediate animal or perceptual experience. However, unlike the animistic theory which involves dreams (the descending trajectory of the autistic spectrum), Lewis-Williams' theory not only involves altered states of consciousness (the ascending trajectory of the autistic spectrum) but also involves the uses to which it is put by ritual specialists (shamans and priests) in obtaining social advantages in society. It is the fact that the huntergatherer community believes in the efficacy of the potency that shamans claim to access that gives the shaman his or her power.

Lewis-Williams used the rich ethnographical literature and the very rich rock art remains of southern Africa to bolster his theory of shamanism and altered states of consciousness. These include the more than 12000 pages of transcribed and translated interviews with San prisoners, some of them possibly shamans, by the German linguist Wilhelm Bleek and his partner Lucy Lloyd at the end of the 19th century, including comments elicited by them about copies of rock paintings from their / Xam San informant Diä!kwain. Also relevant is the article on San folk lore published by Orpen (1874), which records (in English) San stories told to him by his informant Qing whilst on an expedition in the Drakensberg in 1873 (Lewis-Williams 2004:188). LewisWilliams' mastery of the language of the Bleek and Lloyd collection and his extensive cross-referencing of the collection ensure that his theories are firmly grounded on the most significant and extensive ethnographical literature. His publications also include subtle readings of several San myths, recently republished in book form (2015). According to Lewis-Williams ritual, the trance dance and altered states of consciousness are often the key to the San myths or folk tales.

\section{Potency in San religions}

When Bleek presented to Diä!kwain copies of the rock paintings, he stated that they 'depicted a!khwa-ka xorro, and the people associated with it were !kwa-ka !gi:ten' (LewisWilliams 2002:136). Lewis-Williams (2002) explained:

Amongst the many things hitherto unintelligible were beliefs about !gi:ten (sing.: !gi:xa). One of the words that Diä!kwain used when he responded to copies of rock paintings that Orpen had made in the southern Drakensberg. The first syllable of the word, !gi:, means 'supernatural potency', a kind of 'electricity' that / Kaggen, the / Xam trickster-deity, gave to humankind and that resides in all great animals, especially the eland, the largest of all African antelope. The second syllable, $x a$, means 'full of'. A ! gi: $x a$ was thus a person, male or female, who was filled with supernatural potency. (p. 138)

Although Lloyd translated the word as 'sorcerer', a better translation would be 'medicine man' or 'shaman'. This concept is not limited to the /Xam San. The Marshalls, working amongst the Ju/'hoan (!Kung) San in the Kalahari Desert of Namibia and Botswana, some $1200 \mathrm{~km}$ to the North encountered a similar concept (Lewis-Williams 2002):

Lorna Marshall and her daughter Elizabeth found that the $\mathrm{Ju} /$ 'hoansi believed in the effectiveness of people whom they called $n / o m k^{\prime \prime}$ ausi (sing.: $n / o m k^{\prime \prime} a u$ ). Today we know that $n / o m$ is the Ju/'hoan equivalent of ! $g i$, and that $k$ "au means 'possessor' or 'owner'. N/om $k$ "au is thus the equivalent of the /Xam word !gi:xa. About half of the men in any San camp are shamans and about a third of the women. (p. 139)

\section{Lewis-Williams (2002) wrote that:}

It is the task of San shamans [during a trance dance] to activate their supernatural potency, to cause it to 'boil' up their spines until it explodes in their heads and takes them off to the spirit realms - that is, they enter a state of trance at the far end of the intensified trajectory. (p. 139)

As mentioned above, this potency would be used for curing, rain-making, fending off evil spirits, assisting in the hunt and for other purposes. Shamans would have to 'die' in this world in order to enter the spirit world, and would often transform, usually into an animal or half-animal (therianthrope), meeting other spirit animals in the spirit world. Concerning what Native American shamans experienced in trance states, Whitley wrote (2009:179-195), contra Eliade, not of a blissful sense of transcendence or mystical unity but of a fierce power, an often uncomfortable, sometimes painful and usually frightening experience.

Lewis-Williams' carefully considered translation of the terms !gi: and n/om as 'potency' recalls Hewitt's use of the term 'potence' as quoted by Durkheim, and it is tempting to see it as equivalent to the terms 'totemic principle', 'mana' and 'sacred', were it not for the fact that these terms have been debunked and demystified. Indeed, San supernatural potency does seem to be impersonal and connected with the spirit realm above 
where the impersonal Creator God resides (not to be confused with the lesser trickster-god /Kaggen). It also aligns with Guenther's New Animist paradigm of relational ontology and ontological flux, but involves both a universal spiritual power and personal, specific spirits (who are limited expressions of this power). However, this understanding of an impersonal, universal animating force may fall into the trap, discussed by Meylan, of mystifying a term and thereby disguising the sociopolitical uses to which it was put. Ultimately, though, the project of demystification concerns not only the work of religious scholars but also the religions of the societies that they study and the authority of those societies' powerful personages.

Despite some of the apparently totalising claims made by Lewis-Williams' theories, he avoids metaphysical speculation and theological extensions of the term 'potency' and adheres instead to the social, political and historical contexts in which the term was used. Furthermore, he grounds his theories in the ethnographic literature. Even though he discusses San beliefs in most of his work as though they are true, thereby showing respect to them, his Marxist and materialist approach, in effect, demystifies their beliefs. Unlike Durkheim's vague theory that God and religion are society writ large, Lewis-Williams' theories are empirically testable and firmly based on ethnographical literature and cognitive neuroscience. The supernatural potency of San religions does not lie in some putative and reified spirit world but in the imagined efficacy of the ritual specialist's actions and words (including performatives), the imagined efficacy shaman's experiences of altered state of consciousness during the trance dance, and the later depiction of the visionary experiences in rock engravings and paintings in so-called sacred spaces.

\section{Conclusion}

Lewis-Williams' concept of potency bears only superficial similarities to the totemic principle, which Durkheim traced back to Australian Aboriginal religion, apparently unaware of San shamanism, which may be an even older religious tradition. In attempting to reduce religion and God to society, Durkheim began the process of demystification. In one sense, he went too far in his reduction of nature to society, and in another sense, he did not go far enough in that he saw religion purely as a unifying and stabilising force in society. However, his biggest shortcomings were his overestimation of collective affect and sentiment in the foundation of religion, his underestimation of individual psychological experience in the form of altered states of consciousness and his failure to grasp performativity fully. As San belief and ritual suggest, animism is closely connected to the transformations and trance states of shamanism, a multiplex religious tradition that can arguably be traced to the origin of humanity.

\section{Acknowledgements Competing interests}

The author declares that he has no financial or personal relationships that may have inappropriately influenced him in writing this article.

\section{Author's contributions}

R.A.N. is the sole author of this research article.

\section{Ethical considerations}

This article followed all ethical standards for research without direct contact with human or animal subjects.

\section{Funding information}

This research received no specific grant from any funding agency in the public, commercial or not-for-profit sectors.

\section{Data availability}

Data sharing is not applicable to this article as no new data were created or analysed in this study.

\section{Disclaimer}

The views and opinions expressed in this article are those of the author and do not necessarily reflect the official policy or position of any affiliated agency of the author.

\section{References}

Austin, J.L., 1976, How to do things with words: The William James Lectures delivered at Harvard University in 1955, 2nd edn., Oxford University Press, Oxford.

Butler, J., 2015, Notes toward a performative theory of assembly, Harvard University Press, Cambridge, MA.

Derrida, J. 1986, 'Declarations of independence', New Political Science 7(1), 7-15. https://doi.org/10.1080/07393148608429608

Derrida, J., 1988, Limited Inc, Northwestern University Press, Evanston, IL.

Durkheim, E., [1915] 2013, The elementary forms of the religious life, transl. J.D. Swain, Simon \& Brown, New York, NY.

Eliade, M., [1964] 2004, Shamanism: Archaic techniques of ecstasy, Princeton University Press, Princeton, NJ.

Froese, T., 2011, 'From adaptive behavior to human cognition: A review of Enaction', Adaptive Behavior 20(3), 209-221. https://doi.org/10.1177/1059712311433892

Froese, T., Guzmán, G. \& Guzmán-Dávalos, L., 2016, ‘On the origin of the genus psilocybe and its potential ritual use in ancient Africa and Europe', Economic Botany 70(2), 1-12.

Guenther, M., 1999, Tricksters \& trancers: Bushman religion and society, Indiana University Press, Bloomington, IN.

Guenther, M.G., 2017, '“... The eyes are no longer wild. You have taken the kudu into your mind": The supererogatory aspect of San hunting', The South African Archaeological Bulletin 72(205), 3-16.

Guenther, M.,2020a, Human-animal relationships in San and hunter-gatherer cosmology, Volume I: Therianthropes and transformation, Palgrave Macmillan, Cham.

Guenther, M., 2020b, Human-animal relationships in San and hunter-gatherer cosmology, Volume II: Imagining and experiencing ontological mutability, Palgrave Macmillan, Cham.

Lévi-Strauss, C., [1961] 1964, Totemism, transl. R. Needham, Merlin Press, London.

Lewis-Williams, D., 2002, The mind in the cave: Consciousness and the origins of art, Thames \& Hudson, London.

Lewis-Williams, J.D., 2015, Myth and meaning: San-Bushman folklore in global context, UCT Press, Cape Town.

Lewis-Williams, J.D. \& Dowson, T.A., 1988, 'The signs of all times: Entoptic phenomena in Upper Palaeolithic art', Current Anthropology 34, 55-65.

Lewis-Williams, D. \& Pearce, D., 2004, San spirituality: Roots, expressions \& social consequences, Double Storey, Cape Town.

Lewis-Williams, D. \& Pearce, D., 2005, Inside the Neolithic mind: Consciousness, cosmos and the realm of the gods, Thames \& Hudson, London.

Meylan, N., 2017, Mana: The history of a western category, Brill, Leiden.

Orpen, J.M., 1874, A glimpse into the mythology of the Maluti Bushmen, Cape Monthly Magazine (n.s.) 9(49), 1-13.

Petrey, S., 1988, Realism and revolution: Balzac, Stendhal, Zola, and the performances of history, Cornell University Press, Ithaca, NY.

Searle, J.R., 1995, The construction of social reality, Penguin Books, London

Smith, J.Z., 2004, 'Manna, mana everywhere ...', in N.K. Frankenberry (ed.), Radical interpretation in religion, pp. 118-212, Cambridge University Press, New Hampshire.

Whitely, D.S., 2009, Cave paintings and the human spirit: The origin of creativity and belief, Prometheus Books, New York, NY. 